\title{
Editorial
}

\section{The asthma syndrome: inciters, inducers, and host characteristics}

A number of prevailing assumptions about asthma would benefit from re-examination. An example is the view that the host abnormality in asthma is hereditary. Others include the concepts that the abnormality is stable and life-long, the measurement of a normal level of non-specific bronchial responsiveness precludes the possibility of asthma in the individual, and asthma is an entity which is separate and distinct from others such as bronchitis, cystic fibrosis, and pertussis. The position which will be developed here is that these assumptions can now be taken as oversimplifications and, as such, at least partially in error.

Numerous new insights into asthma have emerged from observations of responses to experimental inhalation challenges and observations of the effects of environmental exposures particularly in occupational settings. One type of challenge is the experimental allergen inhalation challenge test in allergic asthmatic individuals-this elicits two basic types of responses, the early (immediate) asthmatic response and the late (non-immediate) asthmatic response. Both may occur in the same individual in the so-called dual asthmatic response. ${ }^{1}$ These responses are mimicked by responses to non-allergic stimuli including airborne chemicals encountered in the workplace. Some theoretical and practical implications of the patterns of responses to various stimuli will be considered here.

\section{Inciters}

Early asthmatic responses develop within minutes of the stimulus and disappear in the first hour or so. The antigen-induced early asthmatic response results from the interaction of antigen with IgE antibody and subsequent release of mediators including histamine and SRS-A which appear to mediate the bronchoconstriction. ${ }^{2} 3$ Short-latency IgG antibody may replace the IgE antibody in some cases. 45

Early responses also result from inhaled histamine, ${ }^{6}$ inhaled methacholine,${ }^{7}$ inhaled cold air, ${ }^{8}$ hyperventilation, ${ }^{9}$ and exercise. ${ }^{10}$ The latter three stimuli apparently operate through heat exchange

Address for reprint requests: Dr J Dolovich, Room 3V41, McMaster Health Sciences Centre, 1200 Main Street West, Hamilton, Ontario, Canada. and the resultant cooling of airways. ${ }^{11}$ The early response to these stimuli, like the early response to antigen, ${ }^{12}$ is not followed by an increase in nonspecific bronchial responsiveness.

The mechanisms underlying the occurrence of early asthmatic responses to non-allergic stimuli remain unclear. Direct evidence of mast cell mediator release is unimpressive despite evidence of inhibition by cromoglycate of the early response stimulated, for example, by exercise. ${ }^{13} \mathrm{~A}$ major dependence upon irritant receptor-vagal parasympathetic reflexes has been postulated ${ }^{14}$ but inhibition by atropine and atropine-like drugs is variable and sometimes unimpressive. ${ }^{15}$ Whatever the pathogenesis, it is abundantly clear that the pre-existing level of nonspecific bronchial responsiveness of the host is a major determinant of the occurrence of early asthmatic responses to both non-allergic and allergic stimuli. The intensity of the stimuli required to provoke a 10 or $20 \%$ fall in $\mathrm{FEV}_{1}$ varies in a linear fashion with the level of non-specific bronchial responsiveness. ${ }^{16-18}$ In other words, the effect of the provoking stimulus is dependent largely upon the preexisting "twitchiness" of the responding bronchi. These stimuli can be considered to incite an effect of the extent permitted by the pre-existing status of the bronchi. The dependence of early responses upon non-specific bronchial responsiveness and the rapid reversibility of these responses suggest that the airflow obstruction is largely a function of reversible smooth muscle contraction.

\section{Inducers}

Late asthmatic responses, occurring as a sequel to an early response (dual response) or in isolation, may be initiated by antigen, ${ }^{119}$ chemically reactive airborne substances such as toluene diisocyanate, ${ }^{20}$ or by endotoxin. ${ }^{21}$ The usual technique of allergen inhalation test in allergic asthmatic individuals is to deliver gradual increases in dose of antigen until there is a

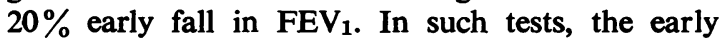
responses are followed by late asthmatic responses in about $50 \%$ of subjects. ${ }^{19}$ The clinical importance of the late responses is indicated by the magnitude, which is often considerably greater than that of the 
corresponding early response, and by the longer duration.

Studies of cutaneous allergic responses have demonstrated that late as well as early responses can occur in reactions in which $\mathrm{IgE}$ antibody is the only specific immune reactant. ${ }^{22} 23$ Rarely, as in birdfancier's lung, IgG rather than IgE antibody appears to be the immune reactant. ${ }^{24}$ Nevertheless, the high frequency of late asthmatic responses after early responses in people with IgE-dependent sensitivity with no other apparently relevant immunological findings, suggests a similar relationship to antibody of the IgE class in the airway that pertains in the skin. The mediators of late responses remain unknown but are a subject of intense investigation. ${ }^{25} 26$ The observations that chemotactic substances including neutrophil chemotactic factor (NCF) and eosinophil chemotactic factor of anaphylaxis (ECF-A) are released in the IgE-dependent reaction have been taken to indicate the possibility that the resulting wave of inflammatory cell infiltration could be responsible for late responses. The possibility that the response is caused by injury produced by liberation from eosinophil granules of major basic protein ${ }^{27}$ is clinically attractive in view of the close relationship of the eosinophil to naturally occurring asthma but this remains unproven. In the skin, fibrin deposition has been invoked as a basis for the inflammatory swelling of the late response. ${ }^{28}$ A number of considerations, taken together, including recent understanding of allergic inflammatory mechanisms, the long duration, the relative resistance to bronchodilators contrasted with susceptibility to adrenocortical steroids suggest a major inflammatory component in the pathogenesis of late responses.

Late asthmatic responses to antigen ${ }^{12}$ and chemically reactive substances, ${ }^{29}$ as well as responses to virus infection ${ }^{30}$ and inhaled pollutants such as ozone, ${ }^{31}$ are associated with the acquisition of increased non-specific bronchial responsiveness. The increase in responsiveness may extend over days, weeks or even months ${ }^{32}$ and may occur in people with a previously normal level of non-specific bronchial responsiveness. In effect, these various stimuli induce asthma as an acquired condition. The recognition of the induction of asthma in these defined conditions raises a larger question; is asthma generally acquired as a result of exposure to inducers, many as yet unknown?

A varying susceptibility to late responses and to increased airway responsiveness seems to be a host characteristic which is otherwise undefined. The late asthmatic responses which occur as a result of antigen inhalation tests vary widely in magnitude. However, repeated antigen inhalation tests in the same allergic asthmatic individual with the same dose of the same antigen usually leads to late responses of similar magnitude (Frith et al, unpublished data). Only a limited number of individuals exposed to asthma inducers in the same occupational environment seem to be at risk to develop late asthmatic responses to challenges and increased non-specific bronchial responsiveness with the attendant features of asthma. No characteristic(s) of the host in the form of a correlate or determinant of susceptibility to inducers of asthma has been recognised; in particular, it has not been identified as hereditary. One or more intercurrent conditions on an acquired basis such as an unusual intensity or persistence of a $\vec{A}$ viral infection or autoimmune process could be 을 involved. Admittedly, numerous observations sug- gest a hereditary basis for asthma. Even in a normal $\mathcal{c}$ non-asthmatic population, there is a range of $\frac{\mathbb{D}}{O}$ responsiveness to inhaled histamine (Thomson and Hargreave, unpublished data). Siblings of asthmatic children have airways which are more labile than those of control children. ${ }^{33}$ There is some concordance of asthma between identical twins. ${ }^{34} \stackrel{\infty}{\rightarrow}$ Unfortunately, these observations are obtained from studies which have not been controlled for the possible influence of known inducers of asthma. The most obvious consideration is that allergy is under major hereditary control ${ }^{35}$ and the allergic reaction is an inducer of non-specific bronchial hyperresponsiveness. The inheritance of allergy together with a normal airway would be expected to lead to a familial clustering of asthma. A relevant reminder here is that an intensive search for genetic markers of asthma such as histocompatibility types has yielded a plethora of conflicting and unconvincing data. ${ }^{36}$

\section{Chronicity}

Anecdotal observations have long suggested that asthma, once acquired from exposure to asthma inducers, can persist after termination of the exposure. For example, firemen with a heavy exposure to spilled toluene diisocyanate on one occasion experienced acute respiratory symptoms which then 0 persisted for many years. ${ }^{37}$ Single (carefully graded) $N$ challenges with asthma inducers in the laboratory may increase responsiveness but it then gradually returns to normal. A recent study has shown that $50 \%$ of western red cedar workers who developed asthma during exposure to western red cedar and $\stackrel{\mathbb{D}}{\rightleftharpoons}$ then changed their occupation continued to have marked increases in non-specific responsiveness at $\overline{0}$ the time of a four-year follow-up (M Chan Yeung, $\mathbb{\otimes}$ personal communication). The persistence was $\underset{\mathbb{D}}{\stackrel{\circ}{ }}$ observed to relate directly to the duration of the occupational exposure after the onset of symptoms. 
Definitive proof of the acquisition of asthma in this type of work and the relationship of the duration of exposure and symptoms to chronicity after the exposure ends will require prospective studies in which subjects are well documented before exposure and are compared with suitable non-exposed controls. It is likely that the intensity and duration of exposure of reacting individuals will prove to be determinants of chronicity.

As a separate issue, the development of irreversibility among some asthmatics, particularly with adult onset asthma, remains problematical. The clinical assumption is that this is part of the disease and is not attributable to alternative potential causes of irreversible airway obstruction including emphysema, cigarette smoking, continuing pollutant exposure, or bronchial infections.

Thus, we know little about the processes operative in the host in asthma induction, chronicity, and irreversibility. It's enough to take your breath away.

\section{Clinical considerations}

The increasingly long list of confirmed inducers of asthma can be expected to continue to lengthen. As a practical point, an increase in non-specific responsiveness demonstrated by repeated histamine or methacholine inhalation tests in association with a particular exposure can be considered to confirm that the substance is relevant to the acquisition of asthma in the individual. Avoidance of offending allergens and chemical inducers can be expected, at least in some cases, to result in a restoration of normal non-specific responsiveness.

Scattered findings indicating increased bronchial responsiveness in conditions such as bronchitis, ${ }^{38}$ cystic fibrosis, ${ }^{39}$ and recurrent croup ${ }^{40}$ are in keeping with the theme, now well supported, that a variety of types of injury can have the common effect of an increase in non-specific bronchial responsiveness. Asthma as defined by Scadding ${ }^{41}$ is not intended to imply a single disease. But the unqualified term "asthma" seems to lend itself to the assumption of a single disease entity. The term asthma has the benefit of a long history of use and should be retained. It refers to a complex situation involving a multiplicity of stimuli, associated conditions, patterns of responses, and probably pathological processes. When the term asthma is used it should be taken to imply the asthma syndrome.

J DOLOVICH, F HARGREAVE

Departments of Pediatrics and Medicine McMaster University Hamilton Ontario, Canada
References

${ }^{1}$ Pepys J, Hutchcroft BJ. Bronchial provocation tests in etiologic diagnosis and analysis of asthma. Am Rev Respir Dis 1975;112:829-39.

${ }^{2}$ Ishizaka K, Ishizaka T. Mechanisms of reaginic hypersensitivity and IgE antibody response. Immunol Rev $1978 ; 41: 109-48$.

${ }^{3}$ Plaut M, Lichtenstein LM. Cellular and chemical basis of the allergic inflammatory response: component parts and control mechanisms. In: Middleton E Jr, Reed Charles E, Ellis EF (eds). Allergy: principals and practice. St Louis: CV Mosby Co, 1978:115-38.

${ }^{4}$ Bryant DH, Burns MW, Lazarus L. Identification of IgG antibody as a carrier of reaginic activity in asthmatic patients. J Allerg Clin Immunol 1975;56:417-28.

5 Gwynn CM, Morrison Smith J, Leon G, Stanworth DR. Role of IgG 4 subclass in childhood allergy. Lancet 1978;1:910-11.

- Cockcroft DW, Killian DN, Mellon JJA, Hargreave FE. Bronchial reactivity to inhaled histamine; a method and clinical survey. Clin Allergy 1977;7:235-43.

7 Townley RG, Dennis M, Itkin IH. Comparative action of acetyl-beta methylcholine histamine, and pollen antigens in subjects with hayfever and patients with bronchial asthma. J Allergy 1965;36:121-37.

${ }^{8}$ Wells RE, Walker JE, Hickler RB. Effects of cold air on respiratory airflow resistance in patients with respiratory tract disease. $N$ Engl J Med 1960;263:268-73.

- Kivity S, Souhrada JF. A new diagnostic test to assess airway reactivity in asthmatics. Bull Eur Physiopathol Respir 1981 ;17:243-54.

${ }^{10}$ Anderson SD, Silverman M, Konig P, Godfrey S. Exerciseinduced asthma. Br J Dis Chest 1975;69:1-39.

${ }^{11}$ Chandler Deal E, McFadden ER Jr, Ingram RH Jr, Breslin FJ, Jaeger JJ. Airway responsiveness to cold air and hyperpnea in normal subjects and in those with hayfever and asthma. Am Rev Respir Dis 1980;121:621-9.

12 Cockcroft DW, Ruffin RE, Dolovich J, Hargreave FE. Allergen-induced increase in non-allergic bronchial reactivity. Clin Allergy 1977;7:503-13.

${ }^{13}$ Silverman M, Andrea T. Time course of effect of disodium cromoglycate on exercise-induced asthma. Arch Dis Child 1972;47:419.

14 Nadel JA. Autonomic control of airway smooth muscle and airway secretions. Am Rev Respir Dis 1977;115:117-26.

${ }^{15}$ Bandouvakis J, Cartier A, Roberts R, Ryan G, Hargreave FE. The effect of ipratropium and fenoterol on methacholine and histamine induced bronchoconstriction. $\mathrm{Br} J$ Dis Chest 1981 ; in press.

16 Cockcroft DW, Ruffin RE, Frith PA et al. Determinants of allergen-induced asthma; dose of allergen, circulating IgE antibody concentration and bronchial responsiveness to inhaled histamine. Am Rev Respir Dis 1979;120: 1053-8.

17 Anderton RC, Cuff M, Frith PA et al. Bronchial responsiveness to inhaled histamine and exercise. J Allergy Clin Immunol 1979;63:315-20.

18 O'Byrne PM, Ryan G, Morris $M$ et al. Cold airinduced asthma: relationship to non-specific bronchial responsiveness to methacholine. AM Rev Respir Dis 1981 ; in press.

19 Robertson DG, Kerigan AT, Hargreave FE, Chalmers R, Dolovich J. Late asthmatic responses induced by ragweed pollen and allergen. J Allerg Clin Immunol 1974; 54:244-54.

20 Butcher BT, Salvaggio JE, Weill H, Ziskind MM. Toluene diisocyanate pulmonary disease: immunological and inhalation challenge studies. J Allerg Clin Immunol 1976; 58:89-100. 
${ }^{21}$ Cavagna G, Foa V, Vigliani EC. Effects in man + rabbit of inhalation of cotton dust or extracts and purified endotoxins. Br J Indust Med 1969;26:314-21.

${ }^{22}$ Dolovich J, Hargreave FE, Chalmers R, Shier KJ, Gauldie J, Bienenstock J. Late cutaneous allergic responses in isolated IgE-dependent reactions. $J$ Allerg Clin Immunol 1973;52:38-46.

${ }^{23}$ Solley GO, Gleich GJ, Jordon ER, Schroeter AL. The late phase of the immediate wheal and flare skin reaction. Its dependence upon IgE antibodies. J Clin Invest 1976;58: 408-20.

${ }^{24}$ Warren P, Sayed HI, Tse KS. Immunologic aspects of hypersensitivity lung disease (HLD) from exposure to avian antigens. J Allerg Clin Immunol 1973;51:104A.

${ }^{25}$ Wasserman SI, Center DM. The relevance of neutrophil chemotactic factors to allergic disease. $J$ Allerg Clin Immunol 1979;64:231-4.

${ }^{26}$ Kaliner MA. Mast cell-derived mediators and bronchial asthma. In: Hargreave FE (ed). Airway reactivity. Mississauga, Canada: Astra Pharmaceuticals Canada Ltd, 1980:175-87.

27 Butterworth AE, Wassom DL, Gleich GJ, Loegering DA, David JR. Damage to schistosomula of Schistosoma mansoni induced directly by eosinophil major basic protein. J Immunol 1979;122:221-9.

${ }^{28}$ deShazo RD, Levinson AI, Dvorak HF, Davis RW. The late phase skin reaction: Evidence for activation of the coagulation system in an IgE-dependent reaction in man. J Immunol 1979;122:692-8.

${ }^{29}$ Vallieres M, Cockcroft DW, Taylor DM, Dolovich J, Hargreave FE. Dimethyl ethanolamine-induced asthma. Am Rev Respir Dis 1977;115:867-71.

${ }^{30}$ Laitinen LA, Elkin RB, Empey DW, Jacobs L, Mills J, Gold WM, Nadel JA. Changes in bronchial reactivity after administration of live attenuated influenza virus. Am Rev Respir Dis 1976;113:194A.
${ }^{31}$ Golden JA, Nadel JA, Boushey HA. Bronchial hyperreactivity in healthy subjects after exposure to ozone. Am Rev Respir Dis 1978;118:287-94.

${ }^{32}$ Contier A, Frith PA, Roberts R, Thomson N, Hargreave FE. Allergen-induced increase in bronchial responsiveness to histamine: relationship to the late asthmatic response and change in airway caliber. $J$ Allerg Clin Immunol 1981; in press.

${ }^{33}$ Konig P, Godfrey S. Exercise-induced bronchial lability and atopic status of families of infants with wheezy bronchitis. Arch Dis Child 1973;48:942-6.

${ }^{34}$ Townley R, Bewtra A, Nair N, Watt G, Burke K, Stekoll L. Chronology of IgE levels, skin test scores and methacholine responses in monozygous (MZ) and dizygous (DZ) twins. Am Rev Respir Dis 1981;123: 49A.

${ }^{35}$ Marsh DG, Bias WB, Ishizada K. Genetic control of basic serum immunoglobulin $\mathrm{E}$ level and its effect of specific reaginic sensitivity. Proc National Acad Sci USA 1974; 74:3588-92.

${ }^{36}$ Dolovich J. Immunologic findings in asthma. In: Hargreave FE (ed). Airway reactivity. Mississauga, Canada: Astra Pharmaceuticals Canada Ltd, 1980:151-5.

37 Axford AT, Mckerrow CB, Parry Jones A, Le Quesne PM. Accidental exposure to isocyanate fumes in a group of firemen. Br J Industr Med 1976;33:65-71.

${ }^{38}$ Simonsson BoG. Clinical and physiological studies on chronic bronchitis. Acta Allergol 1965;XX:325-48.

${ }^{39}$ Mellis CM, Levison $\mathrm{H}$. Bronchial reactivity in cystic fibrosis. Pediatrics 1978 ;61:446-50.

40 Zach MS, Schnall RP, Landau LI. Upper and lower airway hyperreactivity in recurrent croup. Am Rev Respir Dis 1980;121:979-83.

${ }^{41}$ Scadding JG. Definition and clinical categorisation. In: Weiss EB, Segal MS (eds), Bronchial asthma: mechanisms and therapeutics. Boston: Little, Brown and Co, 1976:19-30. 